\title{
『アフリカ研究』50 周年特別号
}

\section{はじめに}

日本アフリカ学会は, 2014 年に創立満 50 年を迎えた。アフリカに対する学術的関心の高まりを背景として, 1964 年 1 月にアフリカ学会設立準備会が発足し, 同年 3 月に, 今西錦司, 岡正雄, 小堀嚴, 中山正善, 西野照太郎, 長 谷川秀治, 福永英二, 松沢勲の 8 名を代表とする 43 名の発起人によって, 日本アフリカ学会の設立が宣言された。 同年 4 月 11 日と 12 日には, 東京大学理学部で創立記念公開講演会と第 1 回大会が開催された。

2011 年 4 月に, 川端正久新会長のもとに発足した理事会では, 50 周年というお抄きな節目にさいして記念事業を 企画・実施することを決定し，理事から構成される日本アフリカ学会創立記念事業検討委員会を設置した。同委員 会は, 2011 年 5 月の理事会・評議員会・総会で承認され, 正式に発足した。この委員会は, 川端会長を委員長とし, 寺嶋秀明副会長，杉山祐子副会長，大林稔理事，重田眞義理事，栗本英世理事の 6 名から構成されていた。翌 2012 年 5 月には, 日本アフリカ学会創立 50 周年記念事業実施委員会（以下，記念事業実施委員会と略称）と改称し, 記 念事業の企画実施を継続した。

記念事業委員会が実施した記念事業は以下のごとくである。各事業の詳細については, 学会 HPに記載されている。

1）『アフリカ学事典』の編集刊行。

記念事業実施委員会のもとに，寺嶋副会長を代表とする 13 名から構成される編集委員会を設置し，編集作業を 行った。日本アフリカ学会編『アフリカ学事典』は, 2014 年 6 月に昭和堂から刊行された。事典は人文科学, 社会科学, 自然科学, 複合領域の 4 部から構成され, 23 分野の総説と 102 項目から成る。執筆者は 125 名であった。

2）記念学術大会と公開講演会の開催。

第 50 回学術大会（2013 年 5 月）と第 51 回学術大会（2014 年 5 月）を記念大会とし，それぞれ公開講演会「ア フリカ研究の誕生——学会創立前後を回顧する」と「アフリカ研究の 50 年」を開催した。前者の公開講演会の 参考資料として冊子『日本アフリカ学会の創立に関わった諸団体と人々』を編集刊行した。

3）国際シンポジウムの開催。

国際シンポジウム「アジアに怙けるアフリカ研究の挑戦とアフリカに㧍けるアジア研究との接点」を, 2014 年 5 月 23 日に京都大学で開催した。組織者は, 岩田拓夫, 峯陽一, 重田眞義の 3 会員。

4）連続講演会の開催。

京都大学アフリカセンターとの共催で, 市民公開講座「アフリカ研究最前線—アフリカ, その魅力と可能性」を, 2013 年 2 月から 2014 年 4 月かけて 8 回にわたって開催した。担当は重田眞義理事。

5）「アフリカ・トーク」の配信。

先進的な研究を行っている若手・中堅会員のインタビューをYou Tube で配信した。現在， 7 番組を配信中。担 当は大林稔理事。

6）支部による講演会・ワークショップの開催。

関東支部が, 2013 年 10 月に《Let's feelアフリカン・ミュージック! 〜講演会＆ダンス・ジェンベ・ワークショッ プ〜》を開催した。主催は, 関東支部と早稲田大学平山郁夫記念ボランティアセンター, 共催は早稲田大学国際 コミュニティセンター。

7）「アフリカ研究セミナー」の開催。

2013 年 3 月に, 韓国外国語大学校アフリカ研究所で「アフリカ研究セミナー」で開催した。龍谷大学社会科学 研究所と韓国外国語大学校アフリカ研究所が締結した学術交流協定に基づく。

8） 在籍 50 年会員の顕彰

第 50 回学術大会において, 学会創立年度から連続して在籍している以下の会員 13 名を顕彰した。安藤勝美, 岩 城剛, 奥野保男, 小田英郎, 河合雅雄, 川田順造, 諏訪兼位, 端信行, 原口武彦, 日野舜也, 宮治美江子, 吉田 昌夫, 和田正平。 
9）功労賞の授与

第 51 回学術大会に扔いて, 本学会の運営と発展に功績のあった 6 名の元会長一一市川光雄, 小田英郎, 北川勝彦, 諏訪兼位, 田中二郎, 宮本正興——に功労賞を授与した。

10『アフリカ研究』特別号の編集刊行。

本特別号は，記念事業実施委員会が企画・実施した，上記の 10 番目の事業の成果である。通常の号とは異なり， 記念事業実施委員会のもとに設置された, 栗本英世理事を委員長とし, 池野旬会員, 中野良彦会員, 松田素二会員 を委員とする特別号編集委員会が編集業務に従事した。

本特別号は 4 部から構成されている。第 1 部は, 創立 50 周年記念学術大会であった第 51 回学術大会に扔いて開 催された公開講演会「アフリカ研究の 50 年」(2014 年 5 月 24 日, 京都大学百周年時計台記念館百周年記念ホール) の講演録である。在籍 50 年顕彰を受けた 13 名の会員のうち, 小田英郎, 川田順造, 原口武彦, 宮治美江子, 吉田 昌夫の 5 会員が講演を行った。なお同様に, 創立 50 周年記念学術大会であった第 50 回学術大会で開催された公開 講演会「アフリカ研究の誕生——学会創立前後を回顧する」(2013 年 5 月 25 日, 東京大学駒場キャンパス 13 号館 1323 教室）では，在籍 50 年顕彰を受けた 3 会員，奥野保男，諏訪兼位および端信行と浦野起央が講演を行った。

第 2 部には, 在籍 50 年顕彰者のうち, 諏訪兼位会員と日野舜也会員に対して, 2013 年に行ったインタビューを収 録した。学会創立前後の時期の詳細な回顧録である。

第 3 部に収録されているのは, 記念事業実施委員会委員長であり, 前会長である川端正久の論文「日本アフリカ 学会の創立とアフリカ研究の摇籃」である。1950 年代から 1970 年代はじめにかけて, 日本で刊行されたアフリカ研 究関連の膨大な文献と様々な活動が, 本学会の会員以外の者による成果も含めて, 包括的に網羅されている。今後, 本学会の歴史と, 日本に拄けるアフリカ研究の誕生と発展に関心を持つ者にとって, 必須の参照文献となるべき労 作である。

第 4 部には，本学会に関する基礎資料として，「日本アフリカ学会役員リスト（1964～2013）」と「学術大会プロ グラム（第 1 回〜第 27 回)」を収録した。いずれも『アフリカ研究』の「学会記事」に掲載されている情報を編集 したものである。

本特別号の刊行をもって，3 年度にわたって実施された日本アフリカ学会創立 50 周年記念事業は, その幕を閉じ ることになる。この特別号が, 半世紀に㧍よぶ本学会の歴史の記録と継承, そして今後の学会の発展に貢献するこ とを願いつつ, 編集作業を終えたい。

2015 年 2 月 1 日

『アフリカ研究』学会創立 50 周年記念特別号編集員長 日本アフリカ学会創立 50 周年記念事業実施委員会委員 